\title{
Characterization of haemocytes of the Indian edible oyster, Crassostrea madrasensis (Preston)
}

\author{
Gijo Ittoop, Kizhakkayil C George, Nandiath K Sanil, Rani Mary George, Kizhakkecheruvil S \\ Sobhana \& Padmini C Nisha \\ Central Marine Fisheries Research Institute, Kochi, Kerala, India
}

Correspondence: G Ittoop, Division of Physiology, Nutrition and Pathology, Central Marine Fisheries Research Institute, Kochi 682018, Kerala, India. E-mail: achugijo@yahoo.com

\begin{abstract}
The haemocytes of the Indian edible oyster Crassostrea madrasensis were characterized using light and electron microscopy. The light microscopic study was conducted by staining a monolayer of the haemocytes with Geimsa. Cells without granules and with a large nucleus occupying much of the cytoplasmic area were grouped as hyalinocytes. Those with lesser amounts of basophilic cytoplasmic granules were characterized as semigranulocytes and those with large amounts of a mixture of acidophilic and basophilic granules were termed as granulocytes. Ultrastructural studies also revealed the presence of three types of haemocytes. Scanning electron microscopic studies were used to study the spreading behaviour of the haemocytes. Cytochemical studies revealed the presence of acidphosphatase, peroxidase and prophenol oxidase in the cells.
\end{abstract}

Keywords: haemocytes, characterization, ultra structure, enzymes, Crassostrea madrasensis

\section{Introduction}

During the past three decades, considerable interest in how the molluscs defend themselves against pathogens has evolved. Among invertebrates, the molluscan and insect defence systems are being studied extensively in order to understand the basics of the invertebrate immune system. The haemolymph of invertebrates contains plasma and haemocytes. The haemocytes play important roles in defence reactions such as internalization of non-self materials, intracellular digestion, wound healing and toxification/detoxification processes of different xenobiotics. They are also involved in secretion of exoskeleton, transport of calcium and protein regeneration (Cheng 1981). The study of these cells will give an insight into the operation of disease resistance in these animals. Given a lack of identification of molluscan haematopoietic tissues (Cheng 1983), the classification and characterization of the haemocytes is still unclear. No uniform nomenclature for different types of observed haemocytes exists. As, the Indian edible oyster, Crassostrea madrasensis, is an important cultured species in India, the study of its innate immunity is essential for prophylaxis against infectious diseases. The present study attempts to characterize haemocytes of $C$. madrasensis. The study is based on light microscopical, cytochemical and ultrastructural features with an effort to characterize the structure and function of the different types of haemocytes.

\section{Material and methods}

\section{Haemolymph collection}

Edible oysters, C. madrasensis (mean size $6.4 \pm 1.2 \mathrm{~cm}$ $\times 4.3 \pm 0.8 \mathrm{~cm}$ ) collected from the Vembanad Lake at Ernakulam, Kerala, were used for the study. Haemolymph was collected from adductor muscle sinuses (Chen 1996). A notch was filed on the dorsal aspect of the left shell valve adjacent to the adductor muscle. About $0.5-2 \mathrm{~mL}$ of haemolymph was collected from the adductor muscle of each animal using a 27-gauge needle attached to a $5 \mathrm{~mL}$ sterile syringe, transferred to sterile microfuge vials and immediately stored at $4{ }^{\circ} \mathrm{C}$.

\section{Light microscopic studies}

The haemocyte monolayers were prepared and stained as per the method of Bayne, Moore, Carefoot and Thompson (1979) using 10\% Geimsa stain (Merck, Mumbai, India). Briefly, the cells were concentrated by centrifugation at $600 \mathrm{~g}$ for $10 \mathrm{~min}$ at 
$4{ }^{\circ} \mathrm{C}$. The supernatant was discarded and the concentrated suspension of haemocytes was poured onto a clean, grease-free glass slide. The cells were allowed to form a monolayer on the slide by incubating in a moist chamber for $45 \mathrm{~min}$ at $25{ }^{\circ} \mathrm{C}$ and was fixed using $10 \%$ methanol for $15 \mathrm{~min}$, air-dried and stained in Geimsa (diluted 10 times with double-distilled water and filtered before use) for $20 \mathrm{~min}$ and differentiated in acetone. The slides were then observed and photographed using a compound microscope (Leica DMLS, Munich, Germany) under oil immersion objective.

\section{Cytochemical studies}

In cytochemical studies, the presence of enzymes such as acid phosphatase, prophenol oxidase and peroxidase was examined in the haemocytes using the following procedures.

\section{Acid phosphatase}

Following the methods described by Sanders (1974), air-dried haemocyte monolayer was fixed in formalin-acetone (20\% formalin in $50 \%$ acetone) for $1 \mathrm{~min}$ at $0{ }^{\circ} \mathrm{C}$ and rinsed in running tap water. The fixed smears were incubated at $37^{\circ} \mathrm{C}$ for $1 \mathrm{~h}$ in freshly prepared and filtered acid phosphatase substrate solution containing Fast Blue BBN (Sigma, St. Louis, MO, USA). The control slides were incubated in stock substrate solution without Fast Blue BBN. The slides were rinsed in tap water, air-dried, counterstained with $0.1 \%$ neutral red solution (Sisco Research Laboratories, Mumbai, India) for $3 \mathrm{~min}$ and again airdried. The stained slides were then dipped in xylene and mounted with DPX.

\section{Prophenol oxidase}

Air dried haemocyte monolayer was fixed in $2.5 \%$ glutaraldehyde (Merck) in $0.1 \mathrm{M}$ phosphate buffer (pH 7.4) for $1 \mathrm{~h}$ at $4{ }^{\circ} \mathrm{C}$ and washed three times (for $15 \mathrm{~min}$ each) with $0.1 \mathrm{M}$ phosphate buffer ( $\mathrm{pH}$ 7.4). The slides were then incubated in 0.1\% L-DOPA (dihydroxyphenylalanine; Sisco Research Laboratories) prepared in $0.1 \mathrm{M}$ phosphate buffer with $2 \%$ sodium chloride, for $90 \mathrm{~min}$ at $30{ }^{\circ} \mathrm{C}$ and counterstained with dilute Giemsa. Control slides were incubated in $0.1 \mathrm{M}$ phosphate buffer with sodium chloride, but without L-dopa (Smith \& Söderhäll 1983).

Peroxidase

Air-dried haemocyte monolayer on the slide was fixed in $10 \%$ alcoholic formalin for $60 \mathrm{~s}$ and rinsed in distilled water for 15-20 s. Slides were then incubated in myeloperoxidase incubation mixture for $30 \mathrm{~s}$, washed briefly in running tap water, dried and counterstained with Giemsa. Control slides were incubated in 0.1 M phosphate buffer (Sanders 1974).

\section{Electron microscopic studies}

\section{Transmission electron microscopy}

Ultrastructural studies were conducted following the methods of Rasmussen, Hage and Karlog (1985) and Hinsch and Hunte (1990) with modification. The haemolymph was withdrawn from the adductor muscle into three times volume of $3 \%$ glutaraldehyde in 0.1 M sodium cacodylate buffer (Merck, Darmstadt, Germany) containing 12\% glucose (pH 7.8; Sisco Research Laboratories). The haemocyte-fixative solution was mixed well and kept at $4{ }^{\circ} \mathrm{C}$ overnight. The haemocytes were then washed three times in cacodylate buffer and pelletized by centrifugation at $2600 \mathrm{~g}$ for $10 \mathrm{~min}$ at $4{ }^{\circ} \mathrm{C}$. The pellet was post-fixed in $1 \%$ osmium tetroxide (Sigma) for $1 \mathrm{~h}$, again washed in cacodylate buffer three times and centrifuged. The supernatant was discarded and 2\% agarose (Sisco Research Laboratories) in cacodylate buffer ( $\mathrm{pH} 7.8$ ) at $60{ }^{\circ} \mathrm{C}$ was added to the pellet by keeping the microfuge tube in a water bath at $50{ }^{\circ} \mathrm{C}$. The pellet was mixed thoroughly with agarose to disperse the cells uniformly in agarose. It was then allowed to solidify. The solidified agarose cube was cut into $1 \mathrm{~mm}^{3}$ pieces and dehydrated in ascending series of acetone. The dehydrated samples were infiltrated and embedded in Spurr's low viscosity resin (Electron Microscopy Sciences, Fort Washington, WA, USA). Ultra thin sections $(60-90 \mathrm{~nm})$ were cut on an LKB ultrotome Nova (LKB-Produkter AB, Bromma, Sweden), stained with uranyl acetate (Biorad, Watford, UK) and lead citrate (Biorad) and examined under a transmission electron microscope (Hitachi H-600, Tokyo, Japan) at $50 \mathrm{kV}$ accelerating voltage (Dawes 1988).

\section{Scanning electron microscopy}

For scanning electron microscopic studies, freshly collected haemolymph was centrifuged at $160 \mathrm{~g}$ for $10 \mathrm{~min}$ at $4{ }^{\circ} \mathrm{C}$ to concentrate the haemocytes. The concentrated haemocyte suspension was poured onto a clean, sterile cover glass and incubated at $25^{\circ} \mathrm{C}$ for $45 \mathrm{~min}$. After incubation, the monolayer was rinsed with $2 \%$ filtered seawater. The cover slip was cut into small pieces $(3 \mathrm{~mm} \times 8 \mathrm{~mm})$ and each piece with the monolayer of haemocytes was 
preserved in 3\% glutaraldehyde in $0.1 \mathrm{M}$ sodium cacodylate buffer containing $12 \%$ glucose $(\mathrm{pH} 7.8)$ for $2 \mathrm{~h}$ at $4{ }^{\circ} \mathrm{C}$. Subsequently, the samples were washed three times in cacodylate buffer, post-fixed in $1 \%$ osmium tetroxide for $1 \mathrm{~h}$ and again washed three times with cacodylate buffer. The cover slips were air-dried, sputter coated with gold in an ionic coater (Eiko Engineering Company, Mito City, Japan) and examined under a Hitachi-H-6010A scanning system at $50 \mathrm{kV}$ accelerating voltage.

\section{Results}

\section{Light microscopic studies}

The light microscopic studies revealed two cell types. One type of cell contained a small, eccentric, oval to round nucleus and cytoplasm with granules. These granule-containing cells could be further divided into two types. One had abundant granules of eosinophilic and basophilic nature and these were classified as granulocytes (Fig. 1). The other type of cells contained a lesser number of basophilic granules. These were grouped as semigranulocytes (Fig. 2). The smaller cells with a large, round to oval nucleus and a small amount of cytoplasm around the nucleus, without granules, were termed as agranulocytes or hyalinocytes (Fig. 3).

\section{Cytochemical studies}

Acid phosphatase activity was observed as scanty bluish-black dot-like granules in some of the granulocytes and semigranulocytes. However, all the granules within these cells did not show acid phosphatase activity. Acid phosphatase activity was

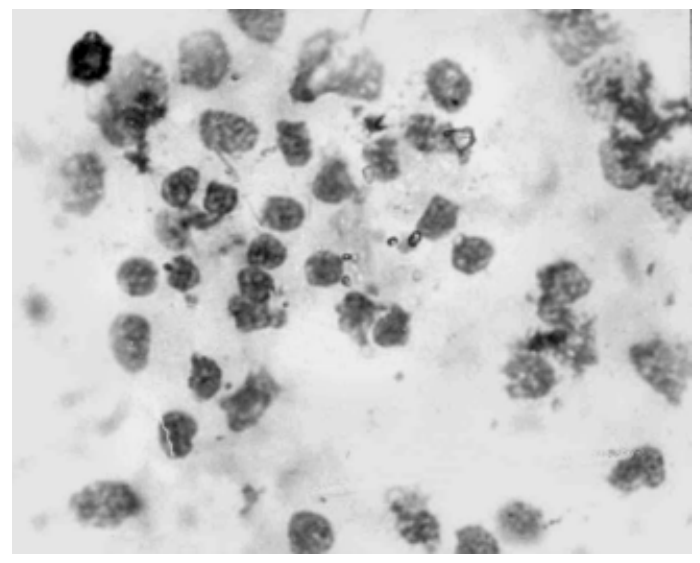

Figure 1 Light microscopic photograph of granulocytes $(\times 100)$.

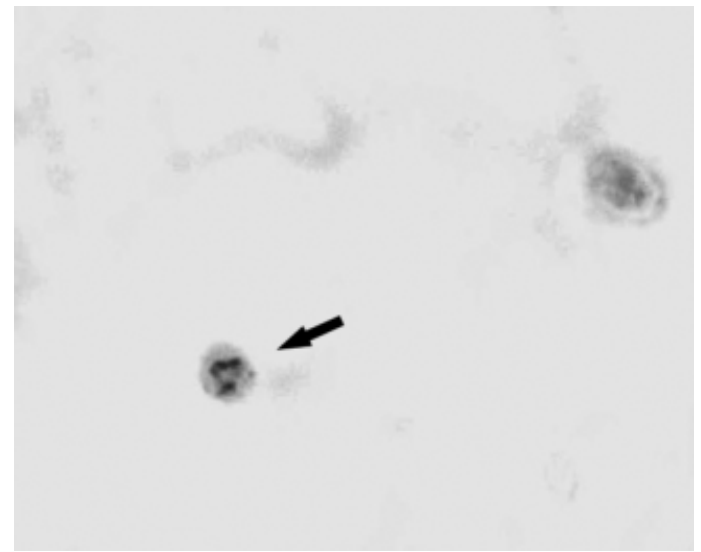

Figure 2 Light microscopic photograph of semigranulocyte $(\times 100)$.

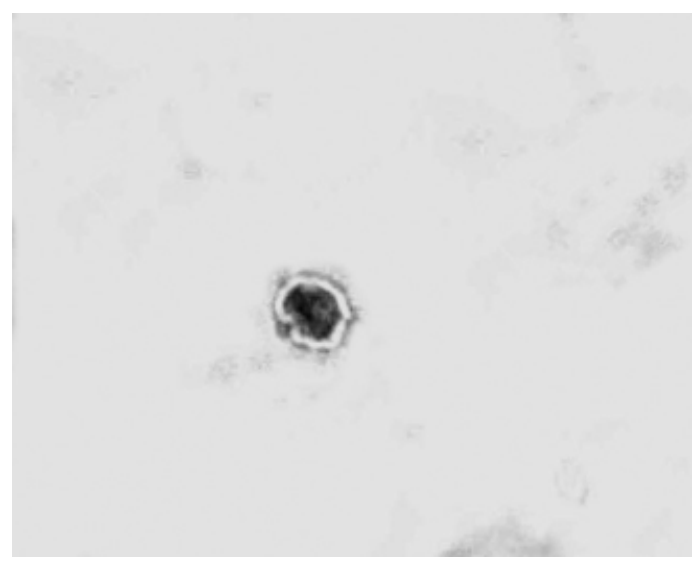

Figure 3 Light microscopic photograph of hyalinolocyte $(\times 100)$.

absent in hyalinocytes (Fig. 4). Prophenol oxidase was observed as a diffused bluish-black pigment in the cytoplasm of many cells. It was also found in the granules in both granulocytes and semigranulocytes (Fig. 5). Peroxidase activity was observed as discrete dark blue granules. These were seen abundantly in all the granulocytes and semigranulocytes (Fig. 6).

\section{Electron microscopic studies}

\section{Transmission electron microscopy}

Electron microscopic examination revealed that hyalinocytes contained a large nucleus with few heterochromatin clumps. Sometimes, three to four nucleoli were also visible in the nucleus. The cytoplasm contained rough endoplasmic reticulum and a few vesicular structures. In these type of cells, the granules 


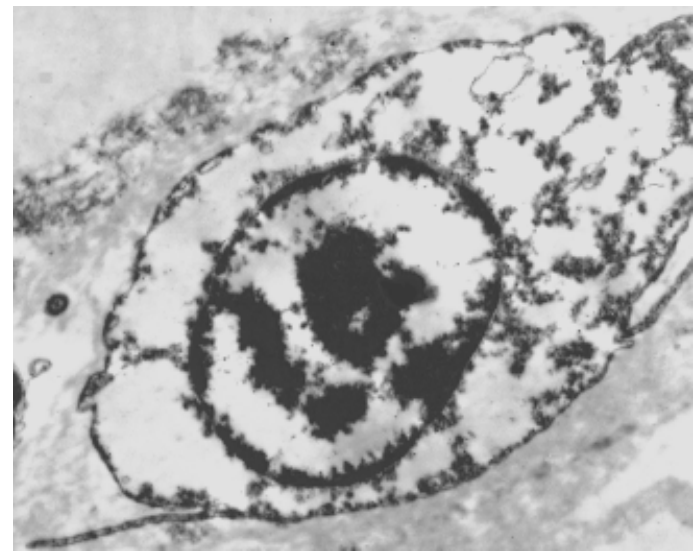

Figure 4 Transmission electron microscopic photograph of a hyalinolocyte $(\times 12000)$.

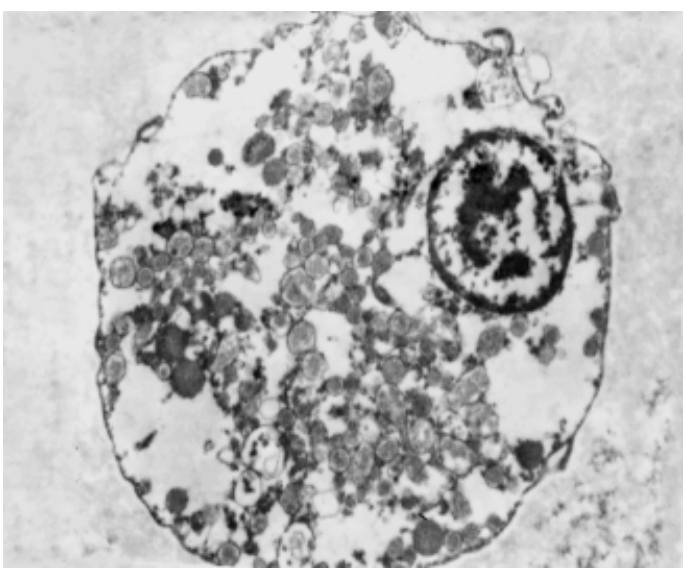

Figure 5 Transmission electron microscopic photograph of a semigranulocyte $(\times 12000)$.

were completely absent (Fig. 7). The cells with distinct membrane bound granules containing electron-lucent materials were categorized as either granulocytes or semigranulocytes, depending on the amount of granules present. The semigranulocytes contained less number of granules with abundant endoplasmic reticulum (Fig. 8). In granulocytes, the granules occupied a major portion of cytoplasm (Fig. 9), and mitochondria were also visible.

\section{Scanning electron microscopy}

In the scanning electron micrographs, the unspread haemocytes were spherical (Fig. 10). Initial pseudopodia were lobose, as they began to spread onto the glass cover slip (Fig. 11). Fully spread haemocytes with branched filopodia with a terminal swelling were also seen (Fig. 12).

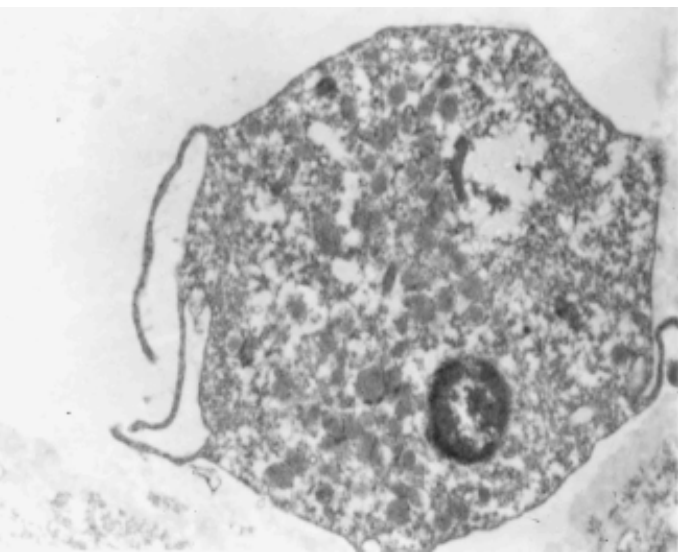

Figure 6 Transmission electron microscopic photograph of a granulocyte $(\times 12000)$.

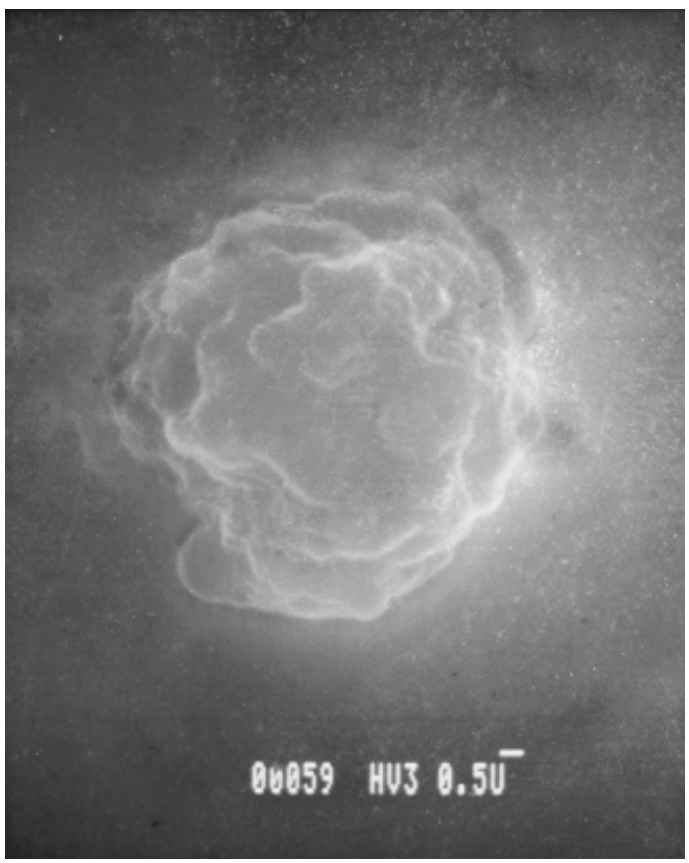

Figure 7 Scanning electron microscopic photograph of an unspread haemocyte.

\section{Discussion}

The haemocytes of molluscs are generally classified into hyalinocytes and granulocytes (Cheng \& Foley 1975; Rodrick \& Ulrich 1984; Rasmussen et al. 1985; Seiler \& Morse 1988; Suresh \& Mohandas 1990a). Granulocytes are further classified into granulocytes and semigranulocytes (Foley \& Cheng 1972; Moore \& Lowe 1977; Rasmussen et al. 1985). The present observations are in agreement with the above findings. Hyalinocytes are generally smaller cells than granu- 


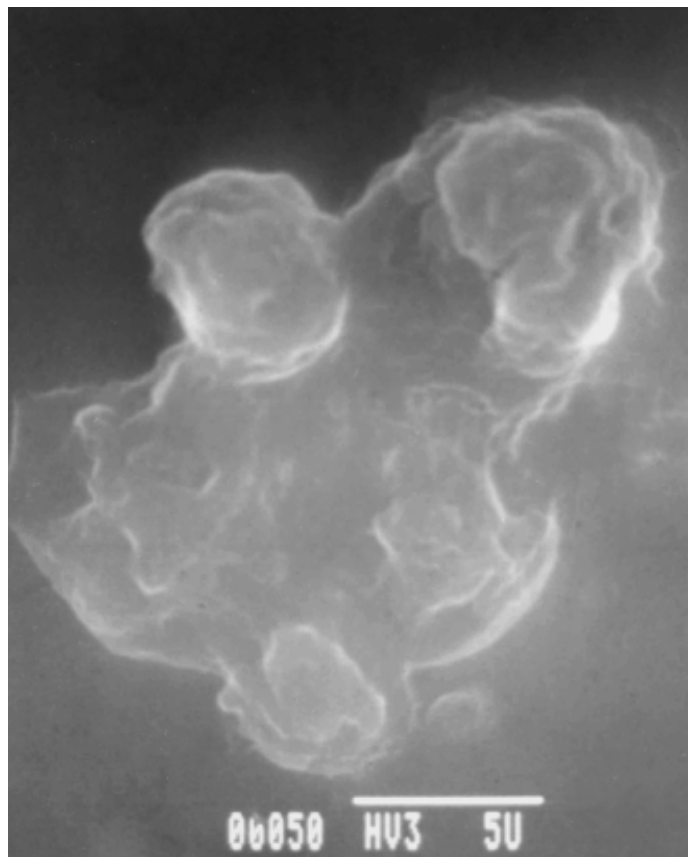

Figure 8 Scanning electron microscopic photograph of a spreading haemocyte with initial pseudopodia.

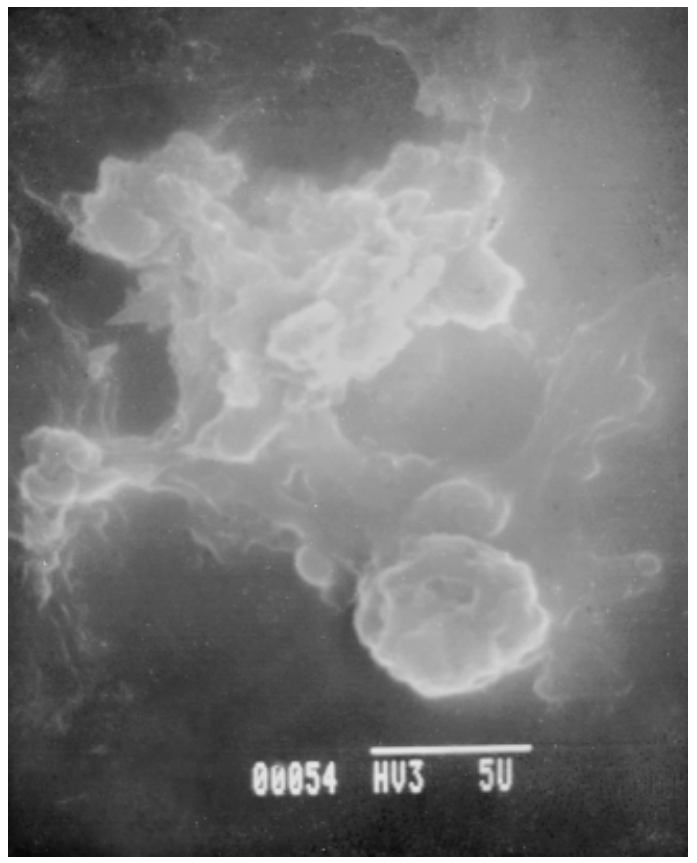

Figure 9 Scanning electron microscopic photograph of a fully spread haemocyte.

locytes. Similar findings were observed in haemocyte populations of Crassostrea virginica (Foley \& Cheng 1972, 1974) and Mytilus edulis (Rasmussen et al.

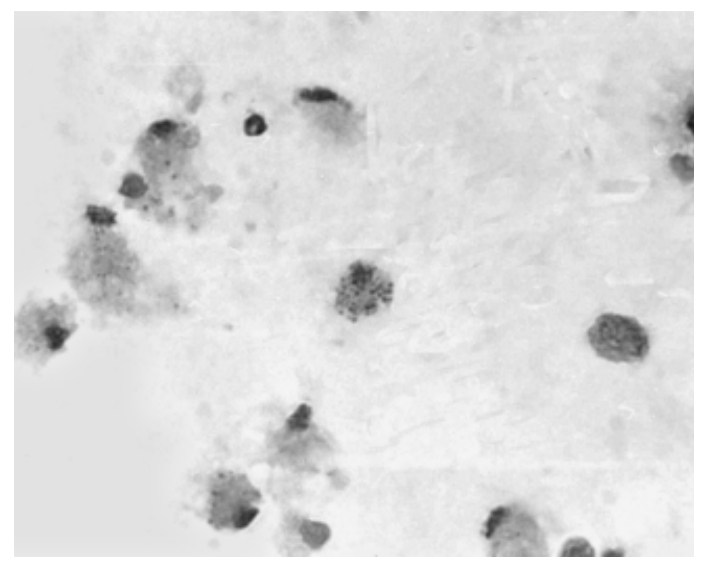

Figure 10 Haemocytes of Crassostrea madrasensis showing acid phosphatase activity $(\times 100)$.

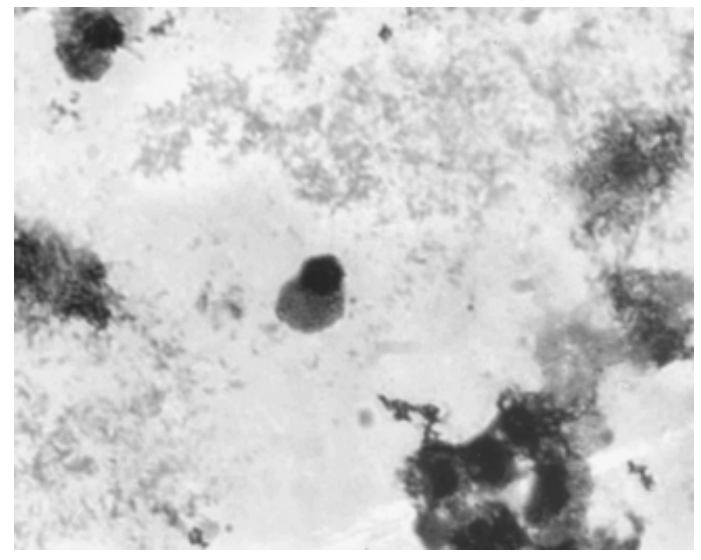

Figure 11 Haemocytes of Crassostrea madrasensis showing prophenol oxidase activity $(\times 100)$.

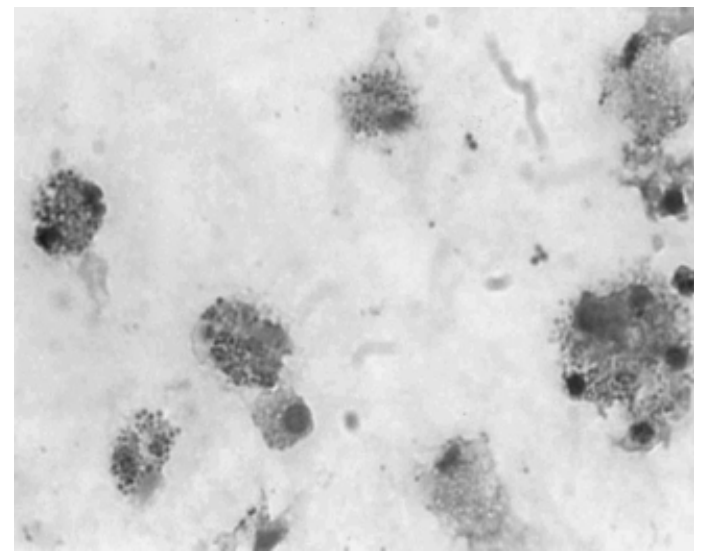

Figure 12 Haemocytes of Crassostrea madrasensis showing peroxidase activity $(\times 100)$.

1985). The granulocytes have either eosinophilic (Bayne et al. 1979; Nakayama, Nomoto, Nishijima \& Maruyama 1997) or a mixture of acidophilic and ba- 
sophilic granules (Foley \& Cheng 1972). In the present study, the granulocytes contained both acidophilic and basophilic granules, whereas semigranulocytes contained only basophilic granules. This finding is very important, as granulocytes are believed to develop from semigranulocytes (Foley \& Cheng 1972; Moore \& Eble 1977; Balquet \& Poder 1985; Rasmussen et al. 1985).

The present study reveals activities of various enzymes such as acid phosphatase, prophenol oxidase and peroxidase in the haemocytes of C. madrasensis. These enzymes have also been demonstrated in other bivalves. Acid phosphatase has been identified in the haemocytes of M. edulis (Moore \& Lowe 1977), Mytilus californianus (Bayne et al.1979), Biomphalaria glabrata (Granath \& Yoshino 1983), Mercenaria mercenaria (Moore \& Gelder 1985), Lymnaea luteola (Jyothirmayi \& Rao 1988), C. virginica (Cheng 1989; Cheng \& Downs 1998), Viviparous ater (Franchini \& Ottaviani 1990), Sunetta scripta and Villorita cyprinoides var cochinensis (Suresh \& Mohandas 1990b), Mya arenaria (Beckmann, Morse \& Moore 1992) and Ruditapes decussatus (Lopez, Carballal, Azevedo \& Villalba 1997). Acid phosphatase and peroxidase play an important role in aggregation and release of the antibacterial agents as reported in Tridacna crocea by Nakayama et al. (1997). It is also reported that acid phosphatase activity is not present in all the granules in the haemocytes of M. mercenaria (Yoshino \& Cheng 1976). In the present study too, acid phosphatase activity was observed only in a few granules within a haemocyte.

In a number of bivalves, the production of reactive oxygen intermediates is absent (Anderson 1994; Torreilles, Guerin \& Roch 1996; Lopez et al. 1997). However, the involvement of the myeloperoxidase system in the production of reactive oxygen intermediates and the subsequent killing of the foreign material has been reported in M. edulis (Schlenk, Garcia Martinez \& Livingstone 1991) and C. virginica (Wojcik \& Paynter 1996). The demonstration of strong peroxidase activity in granulocytes and semigranulocytes of C. madrasensis indicates that the production of reactive oxygen intermediates may also be a major antibacterial mechanism in this species.

Phenol oxidase is the terminal enzyme in the prophenol oxidase system, a complement-like enzyme cascade responsible for the synthesis of melanin, which is deposited in the presence of microbial invaders (Söderhäll 1982). Quinones are formed as byproducts in melanin synthesis and they also play an important role in the destruction of the pathogen. The enzyme is also associated with the generation and release of opsonins for self and non-self recognition (Smith \& Söderhäll 1991). Phenol oxidase is reported to be present in the serum and haemocytes of M. edulis, Argopecten irradians, Placopecten magellanicus, Perna viridis and C. virginica (Coles, Farley \& Pipe 1994; Asokan, Arumugam \& Mullainadhan 1997; Jordan, Deaton, Cardenas \& Dankert 1997; Jordan \& Deaton 2005). However, it is not detected in M. arenaria, M. edulis, Biccinum undatum and Patella vulgata (Smith \& Söderhäll 1991). The present study reveals the presence of this enzyme in the granules of both semigranulocytes and granulocytes.

The electron microscopic studies also revealed three types of cells similar to those observed under light microscopy. The structure of the granulocytes is similar to that in M. edulis (Rasmussen et al. 1985). However, the granules are electron lucent as in the case of C. virginica (Feng, Feng \& Burke 1971). Seiler and Morse (1988) have reported three types of haemocytes in M. arenaria. One type contains electronlucent granules, the second type contains electron opaque granules and the third type has only vesicles in the cytoplasm. In our study, only electron-lucent granules were observed.

The results of scanning electron microscopic observations of spreading haemocytes in C. madrasensis in the present study, and that in Oncomelania hupensis as reported by Morona and Mingye (1989) revealed that the cells spread in the same manner irrespective of the species. Unspread haemocytes were invariably spherical. Adhesion or spreading is made possible by extension or filopodia, which, in our studies, usually had a swollen terminus.

\section{Conclusion}

The results of the present study have clearly shown that three types of haemocytes are present in the Indian edible oyster, C. madrasensis, namely, hyalinocytes, semigranulocytes and granulocytes. The hyalinocytes have no granules and are smaller than the other two cell types and have a large nucleus. The semigranulocytes have a few basophilic granules, while granulocytes have a cytoplasm filled with a large number of acidophilic as well as basophilic granules. The enzymes such as acid phosphatase, peroxidase and prophenol oxidase, which play important roles in the degradation of foreign material, are present mainly in the granules of the haemocytes. The scanning electron microscopic studies have shown that the adhesion of haemocytes to any foreign surface is affected by spreading with the help of 
filopodia. The presence of lysosomal enzymes in the haemocytes and the capacity exhibited by the haemocytes to adhere onto foreign surfaces clearly point towards the role of these haemocytes in internalization and killing of infectious agents. It is believed that this study will provide a base for future studies on innate immunity and immunomodulation in C. madrasensis.

\section{Acknowledgments}

The authors are grateful to the Indian Council of Agricultural Research for the financial support given for this study.We are also indebted to the Director and staff of Central Marine Fisheries Research Institute for the facilities provided to carry out the study.

\section{References}

Anderson R.S. (1994) Hemocyte derived reactive oxygen intermediate production in four bivalve molluscs. Developmental and Comparative Immunology 18, 89-96.

Asokan R.M., Arumugam M. \& Mullainadhan P. (1997) Activation of prophenoloxidase in the plasma and hemocytes of marine mussel, Perna viridis. Developmental and Comparative Immunology 21, 1-12.

Balquet G. \& Poder M. (1985) A consideration of the cellular reactions in bivalve molluscs, with emphasis on haemocytic diseases. In: Fish and Shellfish Pathology (ed. by E.A. Ellis), pp. 381-385. Academic Press, London, UK.

Bayne C.J., Moore M.N., Carefoot T.H. \& Thompson R.J. (1979) Haemolymph functions in Mytilus californianus: the cytochemistry of haemocytes and their response to foreign implants and haemolymph factors in phagocytosis. Journal of Invertebrate Pathology 34, 1-20.

Beckmann N., Morse M.P. \& Moore C.M. (1992) Comparative study of phagocytosis in normal and diseased hemocytes of the bivalve mollusc Mya arenaria. Journal of Invertebrate Pathology 59, 124-132.

Chen J.H. (1996) Haemolymph collection in the Abalone (Haliotis diversicolor). Acta Zoologica Taiwanica 7, 61-71.

Cheng T.C. (1981) Bivalves. In: Invertebrates Blood Cells (ed. by N.A. Ratcliff \& A.F. Rowley), pp. 233-300. Academic Press, London, UK.

Cheng T.C. (1983) Triggering of immunologic defense mechanisms of molluscan shellfish by biotic and abiotic challenge and its application. Marine Technology Society Journal 17, 18-25.

Cheng T.C. (1989) Immunodeficiency diseases in marine mollusks: measurement of some variables. Journal of Aquatic Animal Health 1, 209-216.

Cheng T.C. \& Downs J.C.U. (1998) Intracellular acid phosphatase and lysozyme levels in subpopulations of oyster, Crassostrea virginica haemocytes. Journal of Invertebrate Pathology 52, 163-167.
Cheng T.C. \& Foley D.A. (1975) Haemolymph cells of the bivalve mollusc Mercenaria mercenaria: an electron microscopical study. Journal of Invertebrate Pathology $\mathbf{2 6}$, 341-351.

Coles J.A., Farley S.R. \& Pipe R.K. (1994) Effects of fluoranthene on the immunocompetence of the common marine mussel Mytilus edulis. Aquatic Toxicology 30, 367-379.

Dawes C.J. (1988) Introduction to Biological Electron Microscopy: Theory and Techniques. Ladd Research Industries, Burlington, VT, USA, pp. 315.

Feng S.Y., Feng J.S. \& Burke C.N. (1971) Light and electron microscopy of the leukocytes of Crassostrea virginica (Mollusca: Pelecypoda). Zeitschrift Fur Zellforschung 120, 222-245.

Foley D.A. \& Cheng T.C. (1972) Interaction of molluscs and foreign substances: the morphology and behaviour of haemolymph cells of the American oyster, Crassostrea virginica, in vitro. Journal of Invertebrate Pathology 19, 383-394.

Foley D.A. \& Cheng T.C. (1974) Morphology, hematologic parameters and behaviours of hemolymph cells of the quahog clam, Mercenaria mercenaria. Biological Bulletin 146, 343-356.

Franchini A. \& Ottaviani E. (1990) Fine structure and acid phosphatase localization of hemocytes in the freshwater snail, Viviparus ater (Gastropoda, Prosobranchia). Journal of Invertebrate Pathology 55, 28-34.

GranathW.O. Jr. \& Yoshino T.P. (1983) Characterization of the molluscan phagocyte subpopulations based on lysosomal enzyme markers. The Journal of Experimental Zoology 226, 205-210.

Hinsch G.W. \& Hunte M. (1990) Ultrastructure of the phagocytosis by hemocytes of the American oyster. In: Pathology in Marine Science (ed. by O.F. Perkins \& T.C. Cheng), pp. 479-487. Academic Press, London, UK.

Jordan P.J. \& Deaton L.E. (2005) Characterization of phenoloxidase from Crassostrea virginica hemocytes and the effect of Perkinsus marinus on phenoloxidase activity in the hemolymph of Crassostrea virginica and Geukensia demissa, Journal of Shellfish Research. 24, 477-482.

Jordan P.J., Deaton L.E., Cardenas W. \& Dankert J.R. (1997) Initial characterization of the hemolymph phenol oxidase system in the scallops Argopecten irradians and Placopecten magellanicus. Journal of Shellfish Research 16, 355.

Jyothirmayi G.N. \& Rao P.V. (1988) Possible origin of hemolymph phosphatases in trematode- infected and in non-infected snails. Journal of Invertebrate Pathology $\mathbf{5 2}$, 373-379.

Lopez C., Carballal C.M.J., Azevedo C. \& Villalba A. (1997) Enzyme characterization of the circulating hemocytes of the carpet shell clam, Ruditapes decussatus (Mollusca: Bivalvia). Fish and Shellfish Immunology 7, 595-608.

Moore C.A. \& Gelder S.R. (1985) Demonstration of the lysosomal enzymes in hemocytes of Mercenaria mercenaria (Mollusca: Bivalvia). Transactions of the American Microscopical Society 104, 242-249. 
Moore C.L. \& Eble A.F. (1977) Cytochemical aspects of Mercenaria mercenaria hemocytes. Biological Bulletin 152, $105-119$.

Moore M.N. \& Lowe D.M. (1977) The cytology and cytochemistry of the haemocytes of Mytilus edulis and their response to the experimentally injected carbon particles. Journal of Invertebrate Pathology 29, 18-30.

Morona D. \& Mingye X. (1989) A scanning electron microscope study of granulocytes of Oncomelania hupensis (Mollusca). Journal of Invertebrate Pathology $\mathbf{5 3}$, 116-117.

Nakayama K., Nomoto A.M., Nishijima M. \& Maruyama T. (1997) Morphological and functional characterization of hemocytes in the clam Tridacna crocea. Journal of Invertebrate Pathology 69, 105-111.

Rasmussen L.P.D., Hage E. \& Karlog O. (1985) An electron microscope study of the circulating leucocytes of the marine mussel, Mytilus edulis. Journal of Invertebrate Pathology 45, 158-167.

Rodrick G.E. \& Ulrich S.A. (1984) Microscopical studies on the hemocytes of bivalves and their phagocytic interaction with the selected bacteria. Diseases of Marine Organisms 37, 167-176.

Sanders B.J. (1974) Animal histology techniques. In: Handbook of Laboratory Animal Science (ed. by E.C. Melby Jr. \& N.H. Altman), pp. 117-194. CRC Press, Ohio, USA.

Schlenk D., Garcia Martinez P. \& Livingstone D.R. (1991) Studies on myelopeptidase activity in the common mussel, Mytilus edulis L. Comparative Biochemistry and Physiology 99C, 63-68.

Seiler G.R. \& Morse M.P. (1988) Kidney and hemocytes of Mya arenaria (bivalvia): normal and pollution related ultra structural morphologies. Journal of Invertebrate Pathology 52, 201-214.

Smith V.J. \& Söderhäll K. (1983) Induction of degranulation and lysis of hemocytes in the freshwater cray fish, Astcus astacus by components of the prophenol oxidase activating system in vitro. Cell Tissue Research 233, 295-303.

Smith V.J. \& Söderhäll K. (1991) A comparison of phenol oxidase activity in the blood of invertebrates. Developmental and Comparative Immunology 15, 251-261.

Söderhäll K. (1982) The prophenol oxidase activating system and melanization: a recognition mechanism of arthropods? A review. Developmental and Comparative Immunology 6, 601-611.

Suresh K. \& Mohandas A. (1990a) Number and types of hemocytes in Sunetta scripta and Villorita cyprinoids var cochinensis (Bivalvia) and leukocytosis subsequent to bacterial challenge. Journal of Invertebrate Pathology 55, 312-318.

Suresh K. \& Mohandas A. (1990b) Hemolymph acid phosphatase activity pattern in copper stressed bivalves. Journal of Invertebrate Pathology 55, 118-125.

Torreilles J., Guerin M.C. \& Roch P. (1996) Reactive oxygen species and defense mechanisms in marine bivalves. Comptes Rendus de l'Academia des Sciences, Series 3. Sciences de la vie, Proceedings of the Academy of Sciences 319, 209-218.

Wojcik J. \& Paynter K.T. (1996) Myeloperoxidase activity from bloods cells of the eastern oyster Crassostrea virginica. Journal of Shellfish Research 15, 532.

Yoshino T.P. \& Cheng T.C. (1976) Fine structural localization of acid phosphatase in granulocytes of the pelecypod Mercenaria mercenaria. Transactions of the American Microscopical Society 95, 215-220. 